\title{
CYPRINUS CARPIO: BIOINDICATOR OF HEAVY METAL POLLUTION IN YAMUNA RIVER, DELHI REGION
}

\author{
Sapna Gupta ${ }^{1,2 *}$ (D), Vartika Singh ${ }^{1,3}$ (D) M. L. Aggarwal ${ }^{2}$ \\ ${ }^{1}$ Amity School of Natural Resources \& Sustainable Development (ASNRSD), Amity University, Noida-201313, India \\ ${ }^{2}$ Shriram Institute for Industrial Research, Delhi-110007, India \\ ${ }^{3}$ Amity Institute of Global Warming \& Ecological Studies (AIGWES), Amity University, Noida-201313, India \\ Received - November 02, 2021; Revision - December 13, 2021; Accepted - December 22, 2021 \\ Available Online - December 30, 2021
}

DOI: http://dx.doi.org/10.18006/2021.9(6).805.812

\section{KEYWORDS \\ Bioindicators \\ Heavy metals \\ Bioaccumulation \\ Cyprinus carpio \\ Water-bodies \\ Water quality \\ Ecological health}

\begin{abstract}
Heavy metals being persistent pose conglomerated hazards towards safety and human health. Impacts of heavy metal pollution can be exhibited by both natural and anthropogenic activities. Therefore, developing nations are under immense pressure of controlling the environmental impacts of increasing industrialization and pollution, subject to their limited resources and infrastructure. Bioindicators are important biological entities to determine the positive/ negative changes in the desired ecosystem. They are the fast respondents towards the slightest changes and provide early reliable results. Identifying \& establishing a suitable bioindicator can provide a faster and inexpensive way to address the undesirable effects. Cyprinus carpio, a freshwater fish, is used to determine the Lead $(\mathrm{Pb})$ at different locations of Yamuna River and the bioavailability in different tissues. In the present study, we are trying to establish fish as an indicator of lead pollution in the river. It is a well-known fact that the water bodies are most affected by human activities. Polluted water bodies can lead to adverse effects on human health. Lead is also known to cause phytotoxicities in aquatic and terrestrial plants. This study is therefore an attempt to identify the harmful impacts of lead in River ecology. Ten fish specimens of $C$. carpio were collected from four different sites of Yamuna River and analyzed for Lead accumulation in fish tissues. High concentration and accumulation were observed in specimens collected from various locations and found to be higher than the permissible limits for human consumption.
\end{abstract}

* Corresponding author

E-mail: sapnabgupta@gmail.com (Sapna Gupta)

Peer review under responsibility of Journal of Experimental Biology and Agricultural Sciences.

Production and Hosting by Horizon Publisher India [HPI] (http://www.horizonpublisherindia.in/).

All rights reserved.
All the articles published by Journal of Experimental Biology and Agricultural Sciences are licensed under a Creative Commons Attribution-NonCommercial 4.0 International License Based on a work at www.jebas.org.

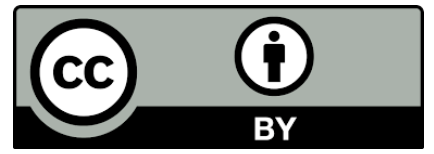




\section{Introduction}

Bioindicators are the biological objects to determine the health of the environment and are helpful in the calculation of possible risks which is associated with certain changes. Natural bioindicators can be useful in identifying the positive and negative environmental changes (Parmar et al., 2016). Various factors like changes in light, wind, temperature, and suspended particles affect the efficiency of bioindicators, which may decide the fate and impact on human settlements. Identifying a perfect species as a bioindicator and applying it to predict the level of contamination can serve as a great tool in addressing water pollution (Khatri \& Tyagi, 2015). A bioindicator is a collective term used to identify ecological reactions that can lead to noticeable changes in living organisms. These bio-indicators can be formed from all sources of biotic/abiotic reactions. Many advantages can be achieved by using bio-indicators.

Ecological factors are completely intertwined together and the smallest change does not simply work on one activity, these factors are monitored to identify the biological impacts. Various species are used to detect any positive/negative impact on normal ecological functions in surroundings (Walsh, 1978; Peterson, 1986; Gerhardt, 2002; Holt \& MIller, 2010). Hasselbach et al. (2005) used Hylocomium splendens (moss) as a bioindicator to monitor heavy metal contamination in the remote tundra of northwest Alaska. Various planktons, lichens, and fish were also used for quantitative estimation of heavy metal load in different waterbodies and associated health risks (Walsh, 1978; Peterson, 1986; Thakur et al., 2013; Azam et al., 2015; Gupta et al., 2020a; Gupta et al., 2020b). Identifying a bioindicator can help in the recognize of Synergistic/ Antagonistic effects of some chemical contaminants. Cyanophytes are used as a bioindicator for Eutrophication in water bodies (Walsh, 1978; Thakur et al., 2013). Bioindicators being real-time changes in an ecological function are very helpful in early diagnosis and accountable to determine the detrimental effects. Natural bioindicators are a reliable and faster way to identify different types of environmental impacts, e.g., Lichens and Bryophytes being used to monitor air pollution (Holt \& MIller, 2010). An early and effective diagnosis eventually becomes an economically viable alternative to all other specialized methods post effect.

Yamuna is a perennial river that flows from Gangotari to Allahabad. Yamuna is the largest tributary to "The Ganges" and covers four Indian states namely Uttarakhand, Uttar Pradesh, Haryana, and Delhi before merging with Ganga. It travels 1376 km from its origin (Ramanathan et al., 1993; Jameel \& Hussain, 2005; Solaraj et al., 2010). In the Delhi region, river flows in from Palla Village and down streams in Jaitpur. It provides livelihood to millions of people during its transverse. Heavy metals' pollution is a growing concern in water bodies due to their non-biodegradable and ubiquitous abundance. Heavy metal accumulation in fish tissues can be sometimes lethal to humans. Common carp ( $C$. carpio) is a widespread species, which is cultured in many parts to manage the food requirements around the world (FAO, 1983; FAO, 2016; HLPE, 2014; Peteri, 2021). This is a non-native species of Yamuna in the Delhi region. Initially, carp was introduced in Yamuna River for ecological balance and addressing the food requirements but now Carp is more available than the indigenous fish species in this region. Increasing population difference of carp v/s other fish species is an indicator of ecological imbalance. Heavy metal accumulation is another challenging condition in the study location. C. carpio has been identified as an important food resource in many countries. It is considered as an important fish for aquaculture and it's important to identify the safety of consumer products (Vilizzi \& Tarkan, 2016). Bio-accumulation of heavy metals in C. carpio was determined in the current study to identify the impacts of pollution on water bodies in the study areas. This study is mainly focused on (i) comparison of catching various fish species and their correlation with different sites. (ii) $\mathrm{Pb}$ accumulation in soft tissues (liver, gills, muscles, \& kidney) of $C$. carpio from four sites in Delhi. (iii) The comparison between heavy metal accumulation in different tissues and their correlation with different sites.

\section{Material and Methods}

\subsection{Sampling location}

Four sampling locations of Yamuna River were selected for sample collection: i.e. Palla Village, Wazirabad barrage, Yamuna Bank near ITO barrage, and Okhla barrage.

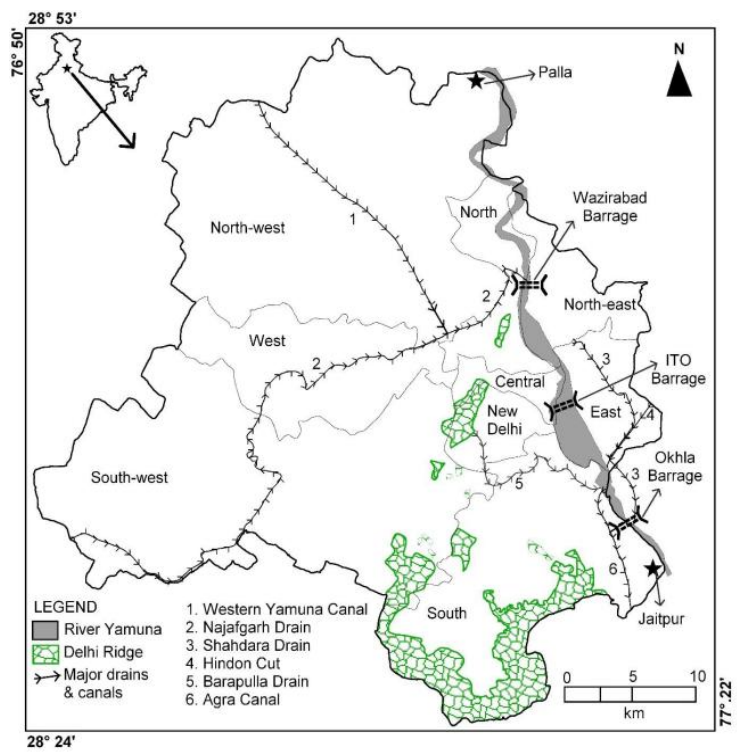

Figure 1 Map of study sites in River Yamuna in the Delhi region. 


\subsection{Sample collection and analysis}

\subsubsection{Sample collection of water}

For physicochemical and heavy metals analysis, water samples were collected in 1 ltr Jerry from all four sites. The samples were collected in duplicate to minimize the bias. Samples for dissolved oxygen were collected separately by fixing the water samples with $\mathrm{MnSo}_{4}+$ alkaline iodide-azide to avoid any skewed results of available oxygen in a $300 \mathrm{ml}$ capacity glass bottle (Baird et al., 2017). The samples were transported to the laboratory within 2 hours of sample collection in an icebox at approx. $4^{\circ} \mathrm{C}$.

\subsubsection{Physico-chemical analysis of water}

Various physicochemical parameters such as $\mathrm{pH}$, dissolved oxygen, free ammonia, suspended solids, and total solids were analyzed in water samples (Baird et al., 2017).

\subsubsection{Heavy-metal analysis of water}

Samples of water were prepared by nitric acid digestion and analyzed using ICP-OES for Heavy metal analysis (Baird et al., 2017). Procedure-related bias was eliminated using a concurrent distilled water blank.

\subsection{Sample collection and preparation of Fish}

Ten fish specimens of $C$. carpio were collected with the help of local fishermen from all sampling sites using a seine net. Fish were transported to the laboratory in frozen conditions within 2 hours of sample collection. These specimens were stored at $-20^{\circ} \mathrm{C}$ until further analysis was carried out. All the fish were grossly examined for any anomaly before the collection of samples for heavy metal analysis.

\subsubsection{Analysis of Fish}

$1 \mathrm{~g}$ wet tissue (gills, muscles, liver, and kidney) was accurately weighed from all the dissected fish and taken for heavy metal analysis. These samples were undergone in closed digestion of microwave digester for 10 minutes run time. In this, $1: 1(5 \mathrm{ml}$ each) concentrated nitric acid and sulphuric acid were used for the digestion process (Baird et al., 2017). After this, these tissues were completely dissolved in the acid mixture to give an elemental form, these samples were further heated on a hot plate in a glass beaker until the acid fumes have vanished. This solution was transferred to a $50 \mathrm{ml}$ capacity volumetric flask and volume was prepared up to $50 \mathrm{ml}$ mark carefully using MiliQ water. An acid blank was also prepared similarly to eliminate any procedural bias. The prepared samples can be stored for up to one month in a glass bottle at $4^{\circ} \mathrm{C}$. All the samples were analyzed using ICP-OES
(Thermofischer). AR grade reagents and solvents were used for sample preparation.

\subsection{Statistical Analysis}

All the findings were subjected to statistical analysis using SPSS version 22.0. One-way ANOVA and Pearson's correlation coefficient test were applied to determine the difference between groups (i.e., sampling locations) and the relationship between Environmental factors and accumulation. The mean and SD were calculated by MS Excel. Kolmogorov-Smirnov and KruskalWallis tests were performed to determine the normality of data. The Kruskal-Wallis test was applied to identify the significant variance at a $95 \%$ confidence level $(\mathrm{p} \leq 0.05)$ (Keshavarzi et al., 2018).

\section{Results and Discussion}

\subsection{Comparison of catching $C$. carpio v/s other fish species and} their correlation

The $C$. carpio fish is not the wild variety to Yamuna river, it was introduced accidentally to the Ganga-Yamuna Ecosystem. The common carp is considered detrimental to fresh water Ecosystem (Pathak et al., 2011). During the sample collection, approximately 3-5 folds more $C$. carpio were caught when compared to other fish in the Yamuna River. The catchment in our study corroborated with previous studies of catching $C$. carpio from the Yamuna river in the Allahabad region (Mayank \& Dwivedi, 2015).

\subsection{Physico-chemical characteristics}

Water samples were analyzed in duplicate for physico-chemical parameters in the laboratory. The $\mathrm{pH}$ of the collected samples was reported in the range of 7.82 to 8.45 with an average value of 8.1. Though the $\mathrm{pH}$ was within permissible limits of drinking water throughout all the locations, the trends indicated that $\mathrm{pH}$ was marginally basic.

Dissolved oxygen of water was critically low in Okhla barrage area found at minimum $(3.5 \mathrm{mg} / \mathrm{l})$ and observed a healthy concentration at Palla village $(8.8 \mathrm{mg} / \mathrm{l})$ with an overall mean of $6.1 \pm 2.62$. Though the mean values of DO are counterfactual of fair health of river water. The water quality of the river was not quite suitable for aquatic lives and other human uses Between ITO to Okhla region (S3\&S4) with a pH lower than 4.0. Ammonia content and Total solids were recorded within the range of permissible/ allowable limits for drinking water as per the World Health Organization and IS: 10500-2012 of Bureau of Indian Standards (Table $1 \&$ 2) (Elder \& Collins, 1991). The suspended matter was tested in the form of Turbidity which was recorded more than the permissible limits of turbidity in drinking water (Gupta et al., 2021). 
Table 1 Physico-chemical components and metal concentration in water $(\mathrm{mg} / \mathrm{l})$ with standard deviation

\begin{tabular}{|c|c|c|c|c|c|c|c|}
\hline \multicolumn{2}{|c|}{ Parameters } & $\mathrm{pH}$ & DO & Free Ammonia & $\mathrm{SS}^{\mathrm{b}}$ & TS & $\mathrm{Pb}$ \\
\hline \multicolumn{2}{|c|}{ IS: $10500,2012^{\mathrm{a}}$} & $6.5-8.5$ & - & 0.5 & $5(10)$ & $500(2000)$ & 0.01 \\
\hline \multicolumn{2}{|c|}{$\mathrm{WHO}^{\mathrm{a}}$} & $6.5-8.5$ & - & 0.5 & - & 500 & 0.05 \\
\hline \multicolumn{2}{|c|}{$\mathrm{CPCB}^{\mathrm{a}}$} & $6.5-8.5$ & $>5.0$ & 0.5 & 10 & $500(2000)$ & 0.01 \\
\hline \multirow{3}{*}{ Palla (S1) } & 1 & 7.82 & 8.6 & 0.1 & 10 & 168 & 0.010 \\
\hline & 2 & 7.86 & 8.8 & BDL & 11 & 176 & BDL \\
\hline & mean & 7.84 & 8.70 & 0.10 & 10.50 & 172.00 & 0.010 \\
\hline \multirow{3}{*}{ Wazirabad (S2) } & 1 & 7.95 & 8.2 & 0.1 & 16 & 248 & 0.010 \\
\hline & 2 & 8.04 & 7.9 & 0.1 & 16 & 260 & 0.010 \\
\hline & mean & 8.00 & 8.05 & 0.10 & 16.00 & 254.00 & 0.010 \\
\hline \multirow{3}{*}{ ITO (S3) } & 1 & 8.16 & 4.3 & 0.3 & 25 & 580 & 0.050 \\
\hline & 2 & 8.16 & 3.9 & 0.3 & 30 & 600 & 0.060 \\
\hline & mean & 8.16 & 4.10 & 0.30 & 27.50 & 590.00 & 0.055 \\
\hline \multirow{3}{*}{ Okhla (S4) } & 1 & 8.45 & 3.5 & 0.2 & 30 & 620 & 0.080 \\
\hline & 2 & 8.38 & 3.8 & 0.4 & 34 & 614 & 0.075 \\
\hline & mean & 8.42 & 3.65 & 0.30 & 32.00 & 617.00 & 0.078 \\
\hline \multicolumn{2}{|c|}{ Overall mean } & 8.10 & 6.13 & 0.20 & 21.50 & 408.25 & 0.038 \\
\hline \multicolumn{2}{|c|}{ Overall SD } & 0.25 & 2.62 & 0.12 & 9.96 & 228.19 & 0.034 \\
\hline
\end{tabular}

!, Gupta et. al, 2021; a, recommended values; b, as turbidity; BDL, Below Detection Limit.

Table 2 Physico-chemical components and metal concentration in water $(\mathrm{mg} / \mathrm{l})$ with standard deviation

\begin{tabular}{|ccc|ccc|}
\hline Parameters & Palla Village & Wazirabad Barrage & ITO Barrage & Okhla Barrage & Overall mean \\
\hline $\mathrm{pH}$ & 7.8 & 8.0 & 8.2 & 8.4 & $8.1 \pm 0.25$ \\
\hline Dissolved oxygen & 8.7 & 8.1 & 4.1 & 3.7 & $6.1 \pm 2.62$ \\
\hline Free Ammonia & 0.1 & 0.1 & 0.3 & 0.3 & $0.2 \pm 0.12$ \\
\hline Suspended solids & 10.5 & 16.0 & 27.5 & 32.0 & $21.5 \pm 9.96$ \\
\hline Total solids & 172.0 & 254.0 & 590.0 & 617.0 & $408.3 \pm 228.19$ \\
\hline Lead content & 0.010 & 0.010 & 0.055 & 0.078 & $0.038 \pm 0.034$ \\
\hline
\end{tabular}

!!, Gupta et. al, 2021.

\subsection{Lead concentration in water}

Water quality concerning the lead concentration at Palla Village and Wazirabad area was following maximum permissible values by WHO/IS: 10500/CPCB i.e., $0.01 \mathrm{mg} / \mathrm{l}$ (WHO, 2012; Gupta et.al, 2021). However, $0.078 \mathrm{mg} / \mathrm{l}$ and $0.05 \mathrm{mg} / \mathrm{l} \mathrm{Pb}$ concentration was observed at Okhla region and ITO location respectively (Table: $1 \& 2$ ). Though the mean Lead concentration of the river was in the permissible limit as per the WHO recommendations viz. $\leq 0.05 \mathrm{mg} / \mathrm{l}$ of water for drinking purposes (WHO, 2012), but it's unacceptable by IS:10500-2012 and CPCB. The variations were noted as the maximum pollution load from Delhi travels in the river from this stretch. Only 2\% of the Yamuna River in Delhi carries approximately $76 \%$ of total pollution (Elder \& Collins, 1991; Gupta et.al, 2021).

\subsection{Heavy metal concentrations in fish from different locations}

Lead concentration in fish tissues was recorded between $0.21 \mathrm{mg} / \mathrm{kg}$ in muscle at Palla Village to $0.36 \mathrm{mg} / \mathrm{kg}$ at Okhla barrage and an overall mean of $0.29 \mathrm{mg} / \mathrm{kg}$ in muscle. Whilst the lowest bio-accumulation $0.11 \mathrm{mg} / \mathrm{kg}$ was recorded in gills of $C$. carpio collected from Palla Village and the highest $(1.18 \mathrm{mg} / \mathrm{kg}$ ) concentration in the Liver from ITO barrage (Table 3). Bioaccumulation is a complex process rendered by various biotic and abiotic factors. Various abiotic environmental factors such as $\mathrm{pH}$, temperature, metal availability, chemical nature of the metal and components, etc., and biotic factors fish age, species, size, feeding, and swimming patterns, and environmental stress affect the bioaccumulation of heavy metals. Stow et al (1994) and

Journal of Experimental Biology and Agricultural Sciences http://www.jebas.org 
Table 3 Location v/s organ wise (mean $\pm \mathrm{SD}$ ) Heavy metal concentration $(\mathrm{mg} / \mathrm{kg}$ b.wt.) in different tissues of $C$. carpio

\begin{tabular}{|ccccccc|}
\hline Parameters & Palla Village & Wazirabad Barrage & ITO Barrage & Okhla Barrage & $\begin{array}{c}\text { Organ-wise mean } \\
\text { accumulation }\end{array}$ \\
\hline Muscle & $0.21 \pm 0.11$ & $0.26 \pm 0.12$ & $0.34 \pm 0.12$ & $0.36 \pm 0.13$ & $0.29 \pm 0.07$ \\
\hline Gills & $0.11 \pm 0.05$ & $0.12 \pm 0.03$ & $0.89 \pm 0.24$ & $0.86 \pm 0.31$ & $0.50 \pm 0.44$ \\
\hline Kidney & $0.32 \pm 0.14$ & $0.33 \pm 0.11$ & $0.86 \pm 0.20$ & $0.88 \pm 0.21$ & $0.60 \pm 0.31$ \\
\hline Liver & $0.57 \pm 0.13$ & $0.59 \pm 0.11$ & $1.18 \pm 0.30$ & $1.08 \pm 0.34$ & $0.85 \pm 0.32$ \\
\hline $\begin{array}{c}\text { Location-wise mean } \\
\text { accumulation }\end{array}$ & $0.30 \pm 0.19$ & $0.33 \pm 0.20$ & $0.82 \pm 0.35$ & $0.79 \pm 0.31$ & $0.56 \pm 0.23$ \\
\hline
\end{tabular}

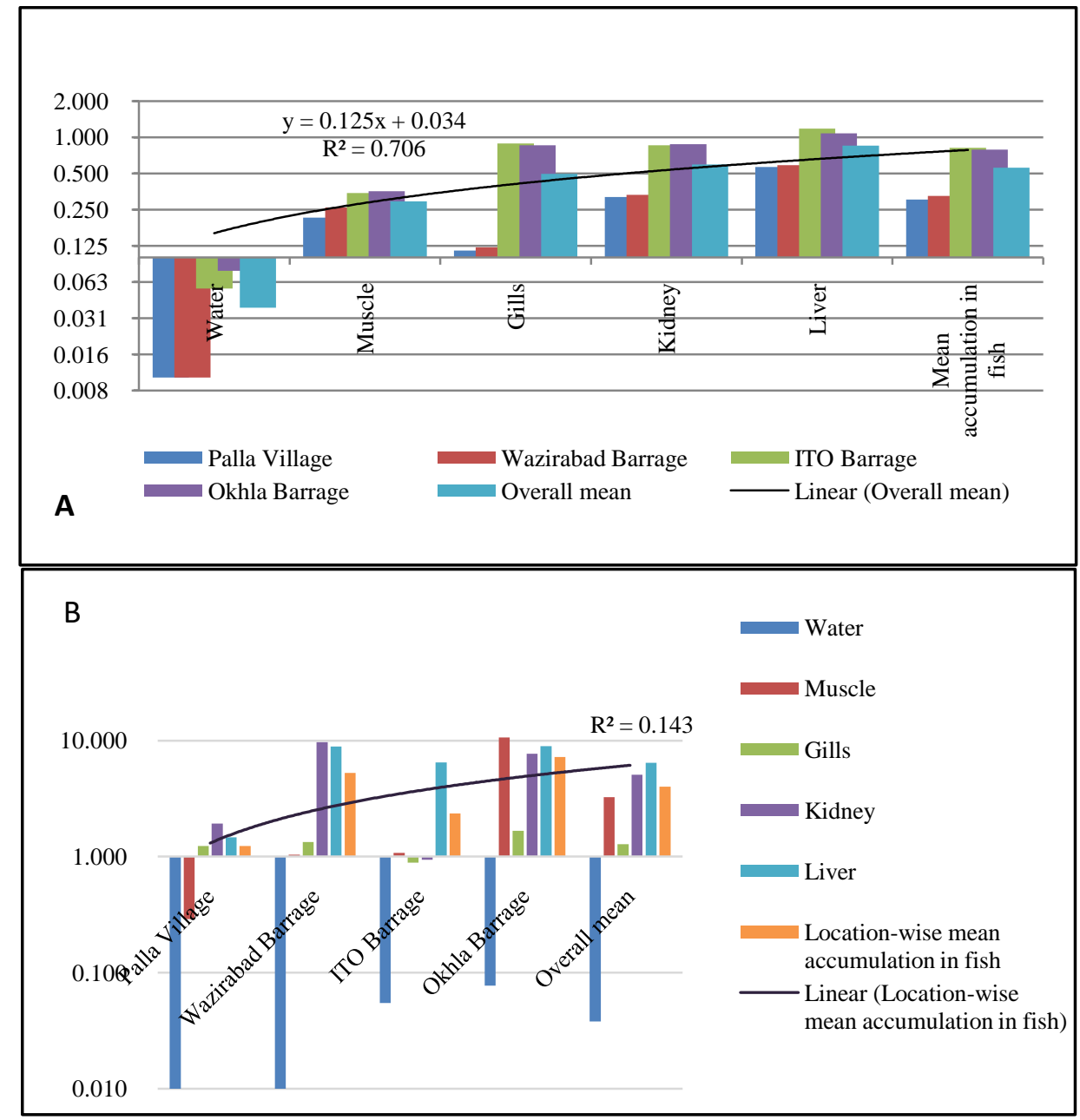

Figure 2 Location wise differences in the lead concentration in different tissues and trend of the mean accumulation in C. Carpio (2A) Locationwise Distribution of Lead in water and various tissues; (2B) Trends of mean Lead Accumulation in different Tissues vs mean location.

Bentzen et al (1996) have explained how the fish habitat and swimming patterns can stimulate and contribute to a higher degree of exposure ending in higher accumulations.

Uptake and absorption of heavy metals in fish is mainly facilitated via two fish systems viz., respiratory and dietary system, among these respiratory systems, works through gills transported via aquatic media (surrounding water) while dietary System works through guts facilitated by sediments and feed (HLPE, 2014).

Variable conditions at different locations thereby impart an important role in bio-accumulation in different fish. Figure 2 suggests the maximum accumulation of Lead in different tissues of C. Carpio happened at ITO barrage, while the lowest 
accumulation occurred at Palla village. The figure also indicates that the liver had the highest tendencies to accumulate the metal whereas muscles had the least affinity towards accumulation.

\subsection{Difference between heavy metal accumulations in differen tissues}

Lead concentration in fish tissues was observed between 0.11 $\mathrm{mg} / \mathrm{kg}$ gills at palla village to $1.18 \mathrm{mg} / \mathrm{kg}$ liver of ITO barrage. As observed, the lowest accumulation was recorded in gills and the highest in the liver. Overall, organ-wise distribution of mean maximum concentration in Liver followed by Kidney > gills > and muscles. Gills of fish collected from the ITO barrage and Okhla barrage have shown a higher affinity of accumulation when compared to muscles (Figure $3 \& 4$ ). These findings suggest these fish are better for human consumption than a previous study on $L$. rohita (Gupta et al., 2021).

Lead in food items can pose serious health implications to human and domesticated animals. $\mathrm{Pb}$ is established to cause neurotoxicity, nephrotoxicity, genotoxicity, etc. (Kalantzi et al., 2013). These toxicities are a challenge for risk assessment as it's being used in various industrial applications. Water being an integral constituent for life and related activities, no ecosystem can sustain itself if water is removed. Therefore, water is a conceivable element to spread the pollution load (OECD, 2006). Further, de Paula Gutiérrez \&Agudelo (2020) have used fish as bioindicators to determine mercury pollution in Colombian water bodies. Results of this study are in agreement with the various previous studies that have been recently published for biomonitoring the effects of heavy metal accumulation and using fish as potential markers for environmental pollution in different ecosystems (Pattanayak et al., 2020; Keke et al., 2020).

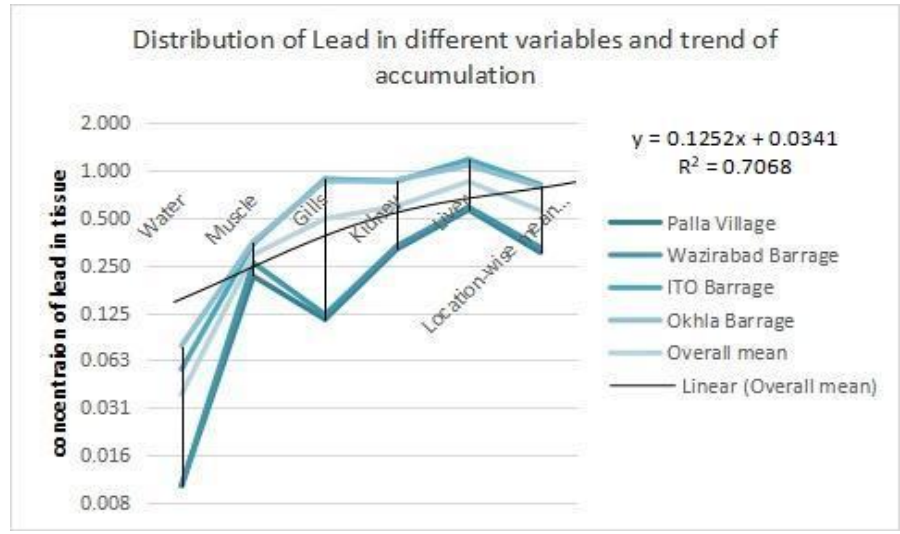

Figure 3 Distribution of lead in different tissues along with the $\mathrm{R}^{2}$ value of mean accumulation.

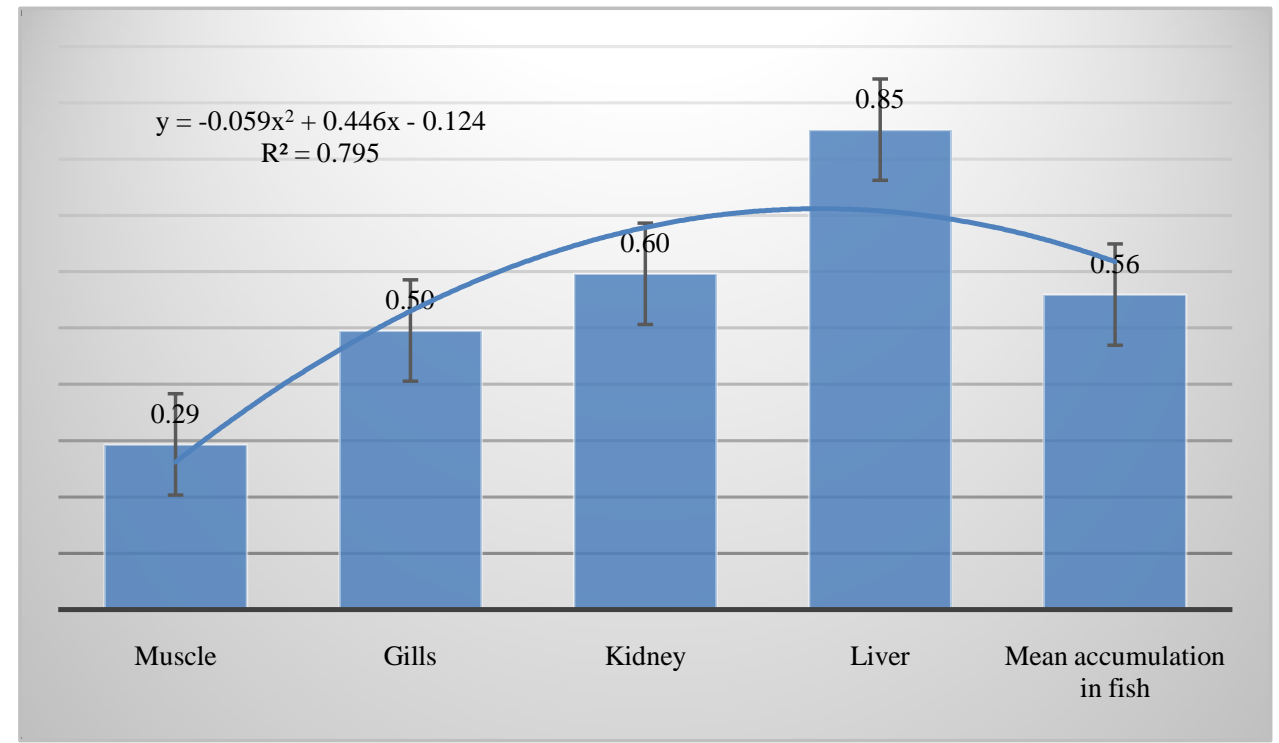

Figure 4 Standard error of $\mathrm{Pb}$ accumulation in different tissues concerning mean $\pm \mathrm{SD}$. The figure shows the relationship of metabolic activity of the tissue with the affinity towards accumulation.

Journal of Experimental Biology and Agricultural Sciences http://www.jebas.org 


\section{Conclusion}

The liver has shown the highest affinity towards lead accumulation followed by kidneys, gills, and muscles. The lower concentrations of organic matter and low pollution is an indicator of lesser accumulation incidences. However, higher organic pollution is an indicator of higher accumulation affinities in muscles. The population density and catch of $C$. carpio over other fish species is itself an indicator of pollution loads in the river, as these fish are considered more adaptable to adverse conditions. Bioaccumulation of lead in C. carpio collected from Palla village, and Wazirabad barrage has shown a trend of Lead accumulation based on the metabolic activity i.e., Liver > Kidney > Muscles > and Gills. But fish collected from ITO barrages and Okhla barrage have shown a different accumulation profile in Liver > Kidney > and gills, though not many changes were recorded in accumulation in muscles from any of four locations. This study reflects the use of C. carpio as a good biomarker for metal pollution in the Yamuna river. However, more extensive research and studies are required to achieve more conclusive results.

Financial Disclosure: None Declared.

Conflicts of Interest: None Declared.

\section{Acknowledgments}

The authors are thankful to Shriram Institute for Industrial Research, Delhi; and Amity University, Noida for facilitating and encouraging the research work. We are heartily grateful to Dr. B.N. Panda, Mr. Raju Joshi, and Dr. D.S. Chatterjee for their technical support while conducting this study, and Mr. Pushpendra Singh, librarian, for providing I\&PR support.

\section{References}

Azam I, Afsheen S, Ahmed Z, Muqaddas J, Saeed R, Sarwar MK, Munir B (2015) Evaluating Insects as Bioindicators of Heavy Metal Contamination and Accumulation near Industrial Area of Gujrat, Pakistan. BioMed Research International DOI: doi.org/10.1155/2015/942751.

Baird R, Eaton AD, Rice EW, Bridgewater LL (2017) Standard methods for the examination of water and wastewater, American Public Health Association (APHA), $23^{\text {rd }}$ Ed. Washington, DC.

Bentzen E, Lean DRS, Taylor WD, Mackay D (1996) Role of food web structure on lipid bioaccumulation of organic contaminants by lake trout (Salvelinus namaycush). Journal of the Fisheries Research Board of Canada 53: 2397-2407. DOI: doi.org/10.1139/f96-196. de Paula Gutiérrez BF, Agudelo CAR (2020) Fish as bioindicators: coal and mercury pollution in Colombia's ecosystems. Environmental Science and Pollution Research 27: 27541-27562. DOI: doi.org/10.1007/s11356-020-09159-4.

Elder JF, Collins JJ (1991) Water Quality Status of River Yamuna, ENVIS Centre on Hygiene, Sanitation, Sewage Treatment Systems and Technology, MoEF, Govt. of India. Reviews of Environmental Contamination and Toxicology 122: 36-79. DOI: doi.org/10.1007/978-1-4612-3198-1_2.

FAO (1983) Compilation of Legal Limits for Hazardous Substance in Fish and Fishery Products. FAO Fishery Circular, No. 464. Food and Agricultural Organization, Rome (1983).

FAO (2016) The State of World Fisheries and Aquaculture 2016, Contributing to food security and nutrition for all, Rome, pp. 200.

Gerhardt A (2002) Bioindicator species and their use in biomonitoring. Environmental monitoring I. Encyclopedia of life support systems. UNESCO Ed. Oxford (UK): Eolss Publisher.

Gupta S, Aggarwal ML, Singh V (2021) Bioaccumulation of Lead in Rohu (Labeo rohita) Fish Collected from Four Different Locations of Yamuna River in Delhi Region. Asian Journal of Chemistry 33(12): 3070-3074. DOI: doi.org/10.14233/ajchem.2021.23468.

Gupta S, Joshi R, Aggarwal ML, Singh V (2020a) Bioaccumulation of Heavy Metals in Freshwater Fish Serving as a Biological Indicator for Water Pollution Load of Yamuna River. Presentation at World Environment Summit 2020, Vallabhbhai Patel Chest Institute University of Delhi, Delhi (India) on Jan 1819, 2020 (pp: 85).http://esdaindia.org/esdacon2020/.

Gupta S, Panda BN, Aggarwal ML, Singh V (2020b) (Abstract) Biological Indicator: Freshwater fish serving as a biological indicator for water quality of Yamuna River in Delhi-NCR region. Oral presentation at National conference on Water Sustainability Conservation, Policy, Ethics and Science, Zakir Husain Delhi College on Jan 21-22, 2020 (pp: 30-31).

Hasselbach L, Ver Hoef JM, Ford J, Neitlich P, Crecelius E, Berryman S, Wolk B, Bohle T (2005) Spatial Patterns of Cadmium and Lead Deposition on and Adjacent to National Park Service Lands in the Vicinity of Red Dog Mine, Alaska. Science of the Total Environment 348: 211-230. DOI: doi.org/10.1016/j.scitotenv.2004.12.084.

HLPE (2014) Sustainable fisheries and aquaculture for food security and nutrition. A report by the High-Level Panel of Experts on Food Security and Nutrition of the Committee on World Food Security, Rome (2014). 
Holt EA, Miller SW (2010) Bioindicators: using organisms to measure environmental impacts. Nature 3(10): 8-13. http://www.nature.com/scitable/knowledge/library/bioindicatorsusing-o.

Jameel AA, Hussain AZ (2005) Water quality index of Uyyakondan channel of river Cauvery at Tiruchirappalli. Indian Journal of Environmental Protection 25 (10): 941-942.

Kalantzi I, Shimmield TM, Pergantis SA, Papageorgiou N, Black KD, Karakassis I (2013) Heavy metals, trace elements and sediment geochemistry at four Mediterranean fish farms. Science of Total Environment 444: 128-137. DOI doi.org/10.1016/j.scitotenv.2012.11.082.

Keke UN, Mgbemena AS, Arimoro FO, Omalu ICJ (2020) Biomonitoring of Effects and Accumulations of Heavy Metals Insults Using Some Helminth Parasites of Fish as Bio-Indicators in an Afrotropical Stream. Frontiers in Environmental Science 8:576080. DOI: doi.org/10.3389/fenvs.2020.576080.

Keshavarzi B, Hassanaghaei M, Moore F, Mehr MR, Soltanian S, Lahijanzadeh AR,Sorooshian A (2018) Heavy metal contamination and health risk assessment in three commercial fish species in the Persian Gulf. Marine Pollution Bulletin 129: 245-252.DOI: doi.org/10.1016/j.marpolbul.2018.02.032.

Khatri N, Tyagi S (2015) Influences of natural and anthropogenicfactors on surface and groundwater quality in rural and urban areas. Frontiers in Life Science 8(1): 23-39. DOI: doi.org/10.1080/21553769.2014.933716.

Mayank P, Dwivedi AC (2015) River health and commercially important catfishes from the Yamuna river, India. Journal of the Kalash Science 3(3): 23-26.

OECD (2006) Summary of Considerations in the Report from the OECD Expert Group on Ecotoxicology, OECD Guidelines for the Testing of Chemicals, Section 2, OECD Publishing, Paris.

Parmar TK, Rawtani D, Agrawal YK (2016) Bioindicators: the natural indicator of environmental pollution. Frontiers in Life Science 9(2): 110-118. DOI: doi.org/10.1080/ 21553769.2016.1162753.

Pathak RK, Gopesh A, Dwivedi AC (2011) Alien fish species, Cyprinus carpio var. communis (common carp) as a powerful invader in the Yamuna river at Allahabad India. National Academy Science Letters 34(9):367-373.
Pattanayak S, Das S, Navyasri K (2020) Bioindicator Emerged as a Potential Environmental Marker. International Journal of Agriculture, Environment and Biotechnology 13(3): 339-344. DOI: dx.doi.org/10.30954/0974-1712.03.2020.9.

Peteri A (2021) Cultured Aquatic Species Information Programme. Cyprinus carpio. Cultured Aquatic Species Information Programme. FAO Fisheries and Aquaculture Division. Rome. [Assessed 21 ${ }^{\text {st }}$ October 2021].

Peterson WT (1986) The effects of seasonal variations in stratification on plankton dynamics in Long Island Sound. In: Bowman MJ, Yentsch CM, Peterson WT (Eds.) Tidal mixing and plankton dynamics. Berlin: Springer-Verlag. Vol. 17 Pp. 225-319.

Ramanathan AL, Vaithiyanathan P, Subramanian V, Das BK (1993) Geochemistry of the Cauvery Estuary, East Coast of India. Estuaries 16: 459-474. DOI: doi.org/10.2307/1352594.

Solaraj G, Dhanakumar S, Murthy KR, Mohanraj R (2010) Water quality in select regions of Cauvery Delta River basin, southern India, with emphasis on monsoonal variation. Environmental Monitoring and Assessment 166: 435-444. DOI:doi.org/10.1007/s10661-009-1013-7.

Stow CA, Carpenter SR, Amrhein JF (1994) PCB Concentration Trends in Lake Michigan Coho (Oncorhynchus kisutch) and Chinook Salmon (O. tshawytscha). Canadian Journal of Fisheries and Aquatic Sciences 51(6):1384-1390. DOI: doi.org/10.1139/f94138.

Thakur RK, Jindal R, Singh UB, Ahluwalia AS (2013) Plankton diversity and water quality assessment of three freshwater lakes of Mandi (Himachal Pradesh, India) with special reference to planktonic indicators. Environmental Monitoring and Assessment 185(10):8355-8373. DOI: 10.1007/s10661-013-3178-3.

Vilizzi L, Tarkan AS (2016) Bioaccumulation of metals in common carp (Cyprinus carpio L.) from water bodies of Anatolia (Turkey): a review with implications for fisheries and human food consumption. Environmental Monitoring and Assessment 188:243. DOI: doi.org/10.1007/s10661-016-5248-9.

Walsh GE (1978) Toxic effects of pollutants on plankton. In: Butler GC (Ed.), Principles of Ecotoxicology. Wiley publication, New York (NY): Pp. 257-274.

WHO (2012) Codex Alimentarius Committee: Joint FAO/ WHO Food Standards Programme Codex Committee on Contaminants in Foods, Maastricht, The Netherlands, Pp. 26-30. 